\title{
Executive Management in Insurance Entities: A Comparative Study of Mutual Companies and Joint-Stock Companies in Spain with a View to the $21^{\text {st }}$ Century Market
}

\author{
by Miguel Ángel Martínez*, Irene Albarrán** and David Camino***
}

\section{Introduction and aims}

Mutual Companies are institutions of the insurance sector and one of the most significant examples of collective ownership entities (Garrido and Comas, 1992). Their activity in Europe, added to that of banking co-operatives represent 15 per cent of continental insurance premiums and in some countries, like the U.K., their share in life insurance business reaches 40 per cent. ${ }^{1}$ These entities are based on the associative-solidary foundation which gave rise to insurance, through people or institutions grouping together and contributing to a common fund. This fund is designed to compensate those who suffer damage due to the accidents or losses covered.

Although trade associations in medieval society had roles involving health insurance (Guilds and Trade Brotherhoods), ${ }^{2}$ it is recognized that insurance mutualism was born in Spain in the 19th century through the Mutual Aid Societies, with more professional management and promoted by workers, the Fire Insurance Mutuals and the Agricultural Mutuals (Garrido and Comas, 1992).

Current formulas for insurance mutualism in Spain are divided into three groups of institutions: "Social Welfare Entities" which cover contingencies supplementary to the state Social Security system; "Occupational Accident Mutuals", which are associations of companies covering risks derived from work-related accidents and illnesses; and, finally, "General Insurance Mutuals" which have freedom to trade in all branches of private insurance. Because of the importance of the latter and their management similarity to "Mercantile Societies" (Article 122 of the Spanish Commercial Code), we shall refer to the management of these companies which, in 1998, meant 57 entities collecting more than 431,000 million pesetas.

Mutual Companies are "associations of persons or institutions to share risks which

\footnotetext{
1 M.A. Martínez Martínez et al., "Las Mutualidades de Seguros Generales como entidades de propiedad colectiva: cambios en su gestión directiva”, Revista Española de Seguros, January 1998, pp. 51-88. Paper submitted to IFSAM Management Conference. Shanghai, 1997.

2 A. Farreres Bochaca, "El Mutualismo de Seguros en España”, AISAM, 40, Paris, 1992.
} uc3m.es

* Universidad de Alcalá and Fundación MAPFRE Estudios, Madrid, e-mail: mam@mapfre.com

** Universidad Complutense de Madrid, e-mail: ialozano@ccee.sis.ucm.es

*** Universidad Carlos III de Madrid and Fundación MAPFRE Estudios, Madrid, e-mail: dcamino@emp. 
individually could befall each of them" ${ }^{3}$, where the insured becomes owner and, at the same time, customer with the differentiating circumstance of being able to participate in electing the management team and in the entity's management.

In view of the almost nil use of other co-operative formulas, the alternative to the Mutuals is found in Joint-Stock Companies which, whilst playing the same role as that described above and attending to their customers, are self-financed and produce a profit for their shareholders.

The advent of increasingly more open and competitive markets has strengthened the role of Joint-Stock Companies as providers of a large part of risk coverage generated all over the world. This is detrimental to the mutual formula whose main weakness lies in the need to grow, the increase of solvency required and their financing. ${ }^{4}$

Mutual Companies have reacted by making major changes to their business structures, even transforming their legal business forms or merging with other groups. As a result, the insurance sector has reinforced its structures, changing management methods and seeking more professional managers. We have studied this issue previously in an analysis carried out in $1997 . .^{5}$

Mutuals were born as entities offering major benefits to their associate members. Therefore, as they are non-profit seekers, their whole orientation is dedicated to improving the service they provide to their members, lowering the cost of their risk coverage. Despite this, this initial associative character has been changing because the small local entities closest to the insured are disappearing and the necessary adaptation of these entities to larger sized markets with higher levels of competitiveness.

The aim of this article is to offer an overview of management and administration in the General Insurance Mutuals sector in Spain, with a similar study of the Joint-Stock Companies, as well as to draw conclusions from comparisons between them taking into account their own executive management strategy.

Our results will be focused on Mutual Company-Joint-Stock Company research, analysing the following:

- Management perceptions about the insurance environment;

- Positions on internal factors regulating the competitiveness of their companies;

- Management systems;

- Entity grouping as to strategies employed.

This contribution allow the authors to complete their previous research on the role of insurance mutualism and the repercussions on the management of such companies.

\section{Insurance in Europe and Spain: structure and trends}

On the threshold of 21 st century, the Spanish insurance market presents new challenges and opportunities to companies. Economic globalization, disappearance of protectionism,

\footnotetext{
3 J. Castelo Matrán and A. Guardiola, MAPFRE Insurance Dictionary, Editorial MAPFRE, Madrid, 1992.

4 E. Redler, "European financial sector. Trends. Practices and effects", Financial Times Management Report, London, 1994.

5 M.A. Martínez Martínez et al., Note 1 above.
} 
communications development through information technology ${ }^{6}$ and the swift evolution of social structures are forcing entrepreneurs to improve their business competitiveness, quickly adapting their organizations to these new conditions.

The most significant economic and social characteristic of the countries forming the European Union is the guarantee they provide regarding a certain privilege of solidarity ${ }^{7}$ with various forms of protection for citizens such as pensions, health systems, disability treatment, children's and senior citizens' care, education, occupational accidents, etc. shaping the mechanisms of what is called the welfare state. Social awareness of the increase in these personal coverages and the impossibility of fully financing them out of state budgets represent new opportunities for the insurance market. ${ }^{8}$

Nowadays, our society is generating other risks. ${ }^{9}$ The reduction and coverage of these risks mean further opportunities for insurance: technological risks (such as pollution and genetics), consumer risks (professional liability, use of products and services), risks due to the use of information (information technology and data processing), etc. are clear examples for this dynamic sector in the western world.

The European insurance sector, formed in 1999 by 4,800 companies, with premiums of $€ 653,512$ million, has grown from 5.6 per cent of the GDP (average of the 15 European Union countries) in 1991 to 7.9 per cent in 1999.

The Spanish market represents 4.9 per cent of the European whole, with 5.4 billion pesetas (€32,327 million) in 1999, and a penetration of insurance of 5.7 per cent of the GDP in the Spanish economy (Table 1).

Amongst the data shown in Table 1, we compare the Spanish situation with the European sector average, attending to amount of premiums, the proportion of life and non-life insurance in the total market, the size of the companies, and insurance penetration with respect to the GDP and number of inhabitants.

Table 2 shows general data for the Spanish market, subdivided into branches.

We have chosen the items below as significant factors to be taken into account in Spain. By adding this comparison to other relevant Spanish market data, we will then identify the most significant trends in the insurance environment at the turn of the century:

(a) Moderate growth in P.C. and car insurance, 47.2 per cent of the market in 1999 (Figure 1). Heavy increases in life insurance over the last few years and various market studies ${ }^{10}$ both indicate that the greatest opportunities for the insurance sector lie in products covering personal risks such as life, health, pensions and care of senior citizens and, on a second level, certain types of asset insurance.

(b) Proliferation of distribution channels through which insurance is sold. The main change

${ }^{6}$ Information-processing systems reach 20 per cent of the insurance sector costs in some countries seeking substantial improvements in business productivity. See: I. Begg and D. Green, "Panorama of key trends in the world Insurance market", South Bank University, London (paper given at the World Insurance Conference, Geneva, 4 July 1996).

7 M.A. Martínez Martínez, "Nuevas necesidades del consumidor de seguros al inicio del siglo XXI: El Caso Español", lecture given at the "2as Xornadas Universitarios do Seguro", Santiago de Compostela, 29 April 1998.

8 According to data of the "Comité Européen des Assurances" (CEA), 1999, Life Insurance in Europe has grown to 61.9 per cent of the total market; in 1991, this just exceeded 48 per cent.

9 J. Attali, "Geopolítica de los riesgos del siglo XXI", Gerencia de Riesgos, 8, 1997.

10 Financial Times Group, "Los seguros en Europa hasta el año 2010. Enfrentarse al reto de los clientes", Newsletter. Recoletos Cía. Ed. Madrid, 1996; N. Byrne, "The European Insurance Outlook 1999-2005", Datamonitor, 1998. 
Table 1:

\begin{tabular}{|c|c|c|c|c|c|c|}
\hline \multirow[b]{2}{*}{ Magnitude } & \multicolumn{3}{|c|}{ European Union (15) } & \multicolumn{3}{|c|}{ Spain } \\
\hline & 1992 & 1999 & $\begin{array}{c}\% \\
\text { Annual } \\
\text { growth }\end{array}$ & 1992 & 1999 & $\begin{array}{c}\% \\
\text { Annual } \\
\text { growth }\end{array}$ \\
\hline $\begin{array}{l}\text { Total premiums } \\
\quad(€ \text { million })\end{array}$ & 360,670 & 653,512 & 11.6 & 17,924 & 32,327 & 11.4 \\
\hline$\%$ Premiums/EU total & 100 & 100 & - & 4.9 & 4.9 & - \\
\hline Share (\%) Life/non-life & $48.4 / 51.6$ & $61.9 / 38.1$ & - & $32.1 / 67.9$ & $53.5 / 46.5$ & - \\
\hline Number of companies & 4,974 & 4,800 & $(0.5)$ & 430 & 371 & $(2.0)$ \\
\hline $\begin{array}{l}\text { Average value, annual } \\
\text { premiums per company } \\
\text { (€ million) }\end{array}$ & 73 & 136 & 12.3 & 42 & 87 & 15.3 \\
\hline Total premiums/gdp (\%) & 6.2 & 7.99 & $9-$ & 4.3 & 5.7 & - \\
\hline $\begin{array}{r}\text { Total premiums/ } \\
\text { inhabitant }(€)\end{array}$ & 980 & 1,795 & - & 460 & 859 & - \\
\hline
\end{tabular}

()$=$ Negative values

Source: CEA., June 2000 and SIGMA, September 2000 (in 19991 US\$ = €0.993 (Eurostat))

occurring over the last few years has been the entry of financial institutions into the insurance market where they achieved 44.7 per cent of the total premiums in 1999 and, notably, 73.1 per cent in life insurance premiums. Other channels explored are telesales, department stores, credit cards, Internet, etc. Table 3 (Icea 99) shows this distribution and a comparison of the business share according to 1995 and 1999 figures. In some cases this transformation has gone with strategic alliances between different entities, seeking integration of all financial services in a banking-insurance convergence: "bancassurance", "assurfinance", and "financial conglomerates". ${ }^{11}$

(c) Foreign investments'share in the Spanish insurance sector was estimated, in 1999, at 28.9 per cent of total sector capital. As can be seen in Table 4, the ranking of the first ten major groups includes six entities with foreign interests in 1999 in comparison with only three in 1989.

11 E.U. market deregulation is causing a certain "dynamizing" effect on business with the entry of other suppliers and the influence of the business cooperation alliances, See the following studies: Swiss Re, "Desregulación y apertura del mercado: El Seguro Europeo en el umbral de una nueva era de la competencia" (Market deregulation and opening: European Insurance on the threshold of a new era of competition), Sigma, 7, 1996; L. Van den Bergue and K. Werweire, "Convergence in the financial services industry", The Geneva Papers on Risk and Insurance. Issues and Practice, 25, 2, April, 2000, pp. 262-272; a recent example of a strategic alliance in Spain is the one undertaken by MAPFRE \& CAJAMADRID, which, in January 1998, announced co-operation agreements for their insurance business in Spain and Latin America. 
Table 2:

The Spanish insurance market

(Figures in million pesetas)

\begin{tabular}{|c|c|c|c|c|c|c|}
\hline $\begin{array}{l}\text { Insurance } \\
\text { branches }\end{array}$ & $\begin{array}{c}\text { Premiums } \\
1995\end{array}$ & $\begin{array}{c}\text { Premiums } \\
1996\end{array}$ & $\begin{array}{c}\text { Premiums } \\
1997\end{array}$ & $\begin{array}{c}\text { Premiums } \\
1998\end{array}$ & $\begin{array}{c}\text { Premiums } \\
1999\end{array}$ & $\begin{array}{c}\% \\
\text { Branch }\end{array}$ \\
\hline Car & 859,081 & 869,289 & 846,551 & 899,028 & $1,125,323$ & 21.2 \\
\hline Property and casualty & $1,121,627$ & $1,211,171$ & $1,276,394$ & $1,347,538$ & $1,379,425$ & 26.0 \\
\hline Non-life insurance & $1,980,708$ & $2,080,460$ & $2,122,945$ & $2,246,566$ & $2,504,748$ & 47.2 \\
\hline$\%$ growth & - & 5.0 & 2.0 & 5.8 & 11.4 & \\
\hline Life insurance & $1,372,601$ & $1,635,646$ & $1,907,938$ & $2,043,635$ & $2,796,869$ & 52.76 \\
\hline Total & $3,353,309$ & $3,716,106$ & $4,030,883$ & $4,290,201$ & $5,301,617$ & \\
\hline$\%$ growth & - & 10.8 & 8.4 & 6.4 & 23.5 & 100 \\
\hline
\end{tabular}

Source: D.G.S., Spain 


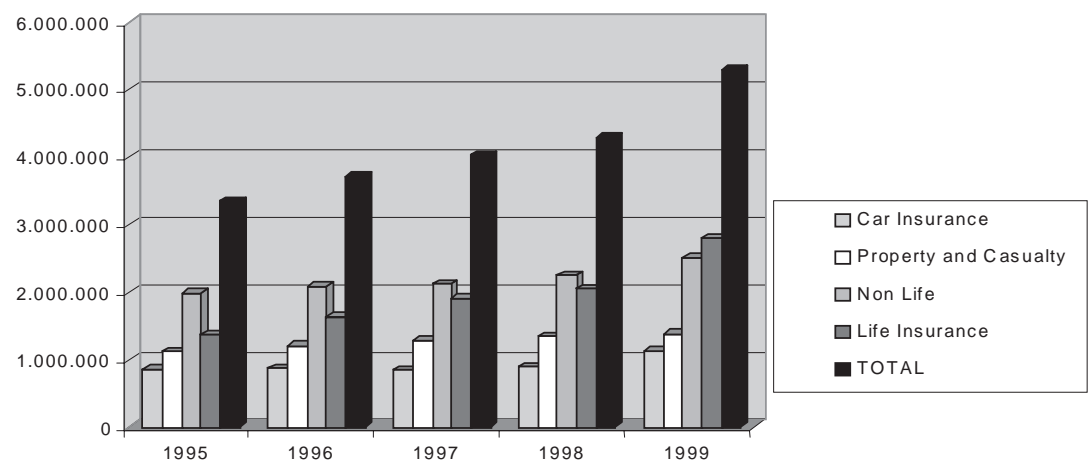

Figure 1: Evolution of the volume of premiums in Spain (million pesetas)

Table 3:

Insurance and distribution channels in Spain

\begin{tabular}{|c|c|c|c|c|c|c|}
\hline \multicolumn{2}{|c|}{$\begin{array}{l}\% \text { Premiums by branch and } \\
\text { channel }\end{array}$} & \multirow{2}{*}{$\begin{array}{c}\text { Agents } \\
33.9\end{array}$} & \multirow{2}{*}{$\begin{array}{c}\text { Brokers } \\
5.3 \\
3.8\end{array}$} & \multirow{2}{*}{$\begin{array}{c}\begin{array}{c}\text { Financial } \\
\text { institutions }\end{array} \\
47.4 \\
52.3^{*}\end{array}$} & \multirow{2}{*}{$\begin{array}{c}\begin{array}{c}\text { Own } \\
\text { offices }\end{array} \\
8.9 \\
5.3\end{array}$} & \multirow{2}{*}{$\begin{array}{c}\begin{array}{c}\text { Other } \\
\text { channels }\end{array} \\
4.5 \\
3.0\end{array}$} \\
\hline $\begin{array}{l}\text { Life } \\
\quad \text { (regular premiums) }\end{array}$ & $\begin{array}{l}1995 \\
1999\end{array}$ & & & & & \\
\hline Car & $\begin{array}{l}1995 \\
1999\end{array}$ & $\begin{array}{l}49.6 \\
51.3\end{array}$ & $\begin{array}{l}19.4 \\
20.8\end{array}$ & $\begin{array}{l}0.6 \\
0.3\end{array}$ & $\begin{array}{l}27.5 \\
18.6\end{array}$ & $\begin{array}{l}2.9 \\
9.0\end{array}$ \\
\hline Multirisk & $\begin{array}{l}1995 \\
1999\end{array}$ & $\begin{array}{l}50.2 \\
62.8\end{array}$ & $\begin{array}{l}19.7 \\
17.5\end{array}$ & $\begin{array}{l}14.7 \\
12.7\end{array}$ & $\begin{array}{r}11.4 \\
5.1\end{array}$ & $\begin{array}{l}4.0 \\
1.9\end{array}$ \\
\hline Health & $\begin{array}{l}1995 \\
1999\end{array}$ & $\begin{array}{l}46.8 \\
24.6\end{array}$ & $\begin{array}{r}13.3 \\
5.3\end{array}$ & $\begin{array}{l}1.3 \\
7.6\end{array}$ & $\begin{array}{l}27.1 \\
57.1\end{array}$ & $\begin{array}{r}11.5 \\
5.4\end{array}$ \\
\hline Total & $\begin{array}{l}1995 \\
1999\end{array}$ & $\begin{array}{l}43.9 \\
31.2\end{array}$ & $\begin{array}{r}16.0 \\
9.6\end{array}$ & $\begin{array}{l}17.7 \\
44.7\end{array}$ & $\begin{array}{l}18.3 \\
11.0\end{array}$ & $\begin{array}{l}4.1 \\
3.5\end{array}$ \\
\hline
\end{tabular}

* 73.1 per cent with single premiums.

Source: ICEA, 2000.

Among Spanish companies working abroad, only the case of MAPFRE is worth mentioning (it is an independent group led by a Mutual Company) as the main insurer in Latin America and leader amongst foreign investors in the non-life insurance in the region.

(d) Low value of premiums issued by each entity: in Spain in 1999, €87 million per entity, in comparison with the European average of $€ 136$ million per entity (Figure 2). An excessively fragmented sector with 366 companies in 1999 (272 were Joint-Stock 
Table 4:

Ranking of the first ten major direct insurance groups in Spain

(Figures in million pesetas)

\begin{tabular}{|c|c|c|c|c|c|}
\hline \multicolumn{3}{|c|}{1989} & \multicolumn{3}{|c|}{1999} \\
\hline Companies & $\begin{array}{c}\text { Total } \\
\text { premiums }\end{array}$ & $\begin{array}{c}\text { Market } \\
\text { share (\%) }\end{array}$ & Companies & $\begin{array}{c}\text { Total } \\
\text { premiums }\end{array}$ & $\begin{array}{c}\text { Market } \\
\text { share (\%) }\end{array}$ \\
\hline BBV & 160,930 & 10.7 & MAPFRE & 359,377 & 7.2 \\
\hline MAPFRE & 102,848 & 6.8 & GENERALI* & 334,864 & 6.7 \\
\hline GRUPO VITALICIO & 84,646 & 5.6 & CAIFOR* & 326,963 & 6.6 \\
\hline LA UNIÓN Y EL FÉNIX & 53,417 & 3.6 & BBV & 276,287 & 5.5 \\
\hline WINTHERTUR* & 47,039 & 3.1 & ALLIANZ* & 243,672 & 4.9 \\
\hline MUTUA MADRILEÑA & 42,461 & 2.8 & AXA* & 175,916 & 3.5 \\
\hline ZURICH* & 42,087 & 2.8 & SANTANDER & 173,510 & 3.5 \\
\hline CATALANA OCCI DENTE & 37,425 & 2.5 & WINTHERTUR* & 163,873 & 3.3 \\
\hline ALLIANZ RAS* & 32,279 & 2.2 & CAJA MADRID & 149,636 & 3.0 \\
\hline LA ESTRELLA & 31,424 & 2.1 & ZURICH* & 141,653 & 2.8 \\
\hline Total, first ten & 634,556 & 42.2 & Total, first ten & $2,345,751$ & 47.0 \\
\hline Total, foreign groups & & 8.1 & Total, foreign groups & & 27.8 \\
\hline
\end{tabular}

${ }^{*}$ Groups with a significant foreign company interest.

Source: Fundación MAPFRE Estudios Reports. 


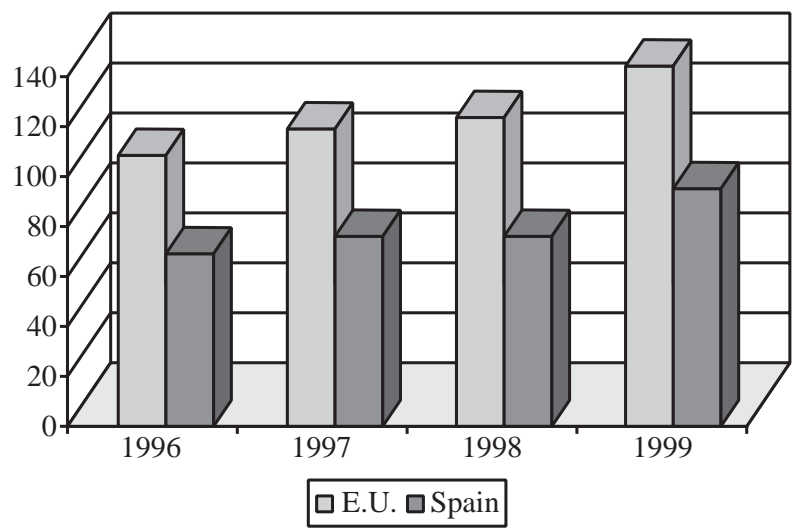

Figure 2: Premiums per company (in million of euros)

Companies, 55 Mutuals and 39 branches of foreign entities) in spite of restructuring carried out (in 1993, there were 456 companies), it is envisaged that concentration processes will accelerate with merger and acquisition strategies.

(e) Despite the historical and current relevance of the mutualist sector ${ }^{12}$ in the world and in Spain, the number of Mutual Companies is decreasing (Figure 3). In 1993, there were 68 Mutual Companies in Spain (13.8 per cent of market premiums) and, in 1998, there were only 57 companies (10\%). This represents a drop of 59 per cent in Mutuals compared with a reduction of 16.2 per cent for the whole of the Spanish entities (Figure 3). Together with the disappearance of some entities, the transformation of Mutuals (a phenomenon known as "demutualization"13) was carried out through merger processes or portfolio assignment to other Mutuals and even through partial or total transformation into JointStock Companies, seeking more flexible business units in the new entity, which could help to solve the problem of financing their growth.

(f) Deregulation and establishment and operational freedom caused by applying the Damage and Life Insurance Directives to Spanish legislation (Act 30/95 on Private Insurance Regulation and Supervision).

As a summary of this framework, we would stress that insurance companies operating in Spain are in a highly competitive market where financial products are mixed with insurance

12 An example of the relevance Mutual Insurance Companies still have is shown by the fact that, in 1999, within the classification of the "largest 500 firms" published in Fortune Review, 18 life and health Mutuals appeared and another three P. and C. (U.S., Japan, Great Britain, Canada, Taiwan and France) with a total of US\$540,511 million reserves. In 1997, the Mutuals Companies represented the 42 per cent premiums in the world. The market share of mutuals in Spain represented 10 per cent in 1998. See: Fortune, "Global 5 Hundred", Fortune, 24 July 2000, pp. 17-18. M.A. Martínez Martínez, D. Camino Blasco, I. Albarrán Lozano, "Las Mutualidades de seguros generales", Revista Española de Seguros, 92, January 1998, pp. 51-88.

13 As an example, see: P. Guinn and S. Collins, "Having it both ways", Best's Review, September 1997, pp. 66-69. M.A. Martínez Martínez et al. (1998) Revista Española de Seguros, 92. Cinco Días, "Prudential reaviva el debate sobre la desmutualización del seguro", Madrid, 16 February 1998. 


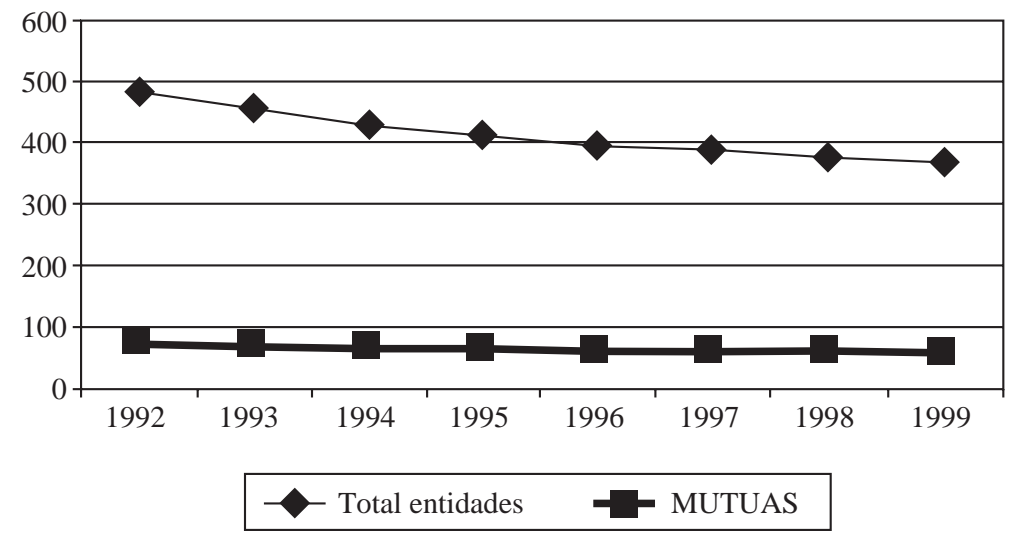

Figure 3: Evolution of the number of insurance and mutual entities in Spain 1992-1999

formulas, where there are new operators, and with a more demanding clientele as regards services provided.

It is expected that flexibility in the organizational structures of companies, improved productivity, and quality directed to insurance processes for creating value for customers ${ }^{14}$ will determine the success of each entity (CAPA, 1996, 1999).

This article will try to study these reasons in depth and the different management models used by Joint-stock Companies and insurance Mutuals in Spain.

\section{Mutual Companies and Joint-Stock Companies}

Shareholders in a Joint-Stock Company exercise their rights and pressure on the senior executive (the agent in the agency theory), ${ }^{15}$ whilst in a Mutual Company, the mutualist has the capacity to exercise his control rights over the agent. ${ }^{16}$

Mutual Companies are organized as an association and their management is carried out by boards elected from amongst their members. These mutualists, inasmuch as they are customers, will behave rationally being interested in high quality, low cost insurance

14 N. Lado Cousté and M.A. Martínez Martínez, "Market orientation and business performance in the Spanish Insurance Sector", The Geneva Papers on Risk and Insurance, October 1997, pp. 571-590.

15 See: E.F. Fama, "Problemas de agencia y teoría de la empresa", Información Comercial Española, July 1984, pp. 53-65; M.C. Jensen and W.H. Meckling, "Theory of the firm", Journal of Financial Economics, 3 (4), October 1976, pp. 305-360.

16 See: J.B. Adkins, "The policyholder perspective on mutual holding company conversions", Journal of Insurance Regulation, 16, autumn 1997, pp. 5-15, Swiss Re, "Las mutuas de seguros. Una especie en peligro de extinción?", Sigma, 4, 1999. 
products, whilst the shareholder in the Joint-Stock Company will demand the highest possible return rate for his investment.

\subsection{Insurance entity management and administration}

The well-known social object of Mutual Companies ${ }^{17}$ leads them to be characterized by a lack of profit-seeking, whilst in a Joint-Stock Company, the main objective is dominated by the economic nature of capital investment.

Both institutions are under pressure from market competitors, and both must maximize their efficiency and attention to customers. Profits obtained by the Mutual Company, which is not used to lower the cost of the policies sold, will serve to build up financial reserves and improve its solvency or attend to business growth. The Joint-Stock Company has greater opportunities when seeking finance in capital markets, and can thus supplement its own selffinancing capability.

According to current Spanish law (Act 30/1995 on Private Insurance Regulation and Supervision, Commercial Code and the Companies Act 22/12/1989), both types of entity are characterized by the management peculiarities shown in Table 5 .

As far as the internal organization of companies is concerned, the law recognizes that each entity's own rules (statutes) may appoint other boards to manage them.

In practice, their organizational design is undergoing profound transformations ${ }^{18}$ to adapt to new international competition and to a demand market with greater service requirements. This involves (see Figure 4) overcoming the functional dimension based on specialized technical tasks in companies (1) to generate structures able to optimize the specific business processes (2) of each branch (3) and at once to integrate institution potentials by segmentating its offer by types of customers (4).

\subsection{Mutual Companies and Joint-Stock insurance Companies in Spain}

In 1998, insurance Mutuals represented 10 per cent of the Spanish market. Ten major entities represented 83.7 per cent of mutualist production themselves whilst ten major JointStock Companies represented 26.8 per cent of its insurance production. These figures give an idea of the problem involving the size of the Mutuals compared to the remaining entities. ${ }^{19}$

Table 6 (1999) shows the top ten entities for each form of company, including the absolute market share of each one, out of the Spanish total. Except for two mutual entities, the data comparison in Table 6 shows differences in firms' size and their relative influence in the large entity market.

\footnotetext{
${ }_{17}$ M.H. Maleville, "Vers un statut de la mutualité europénne", Revue Générale des Assurances, Paris, 14, p. 741.

18 M.A. Martínez Martínez, Organización y Estrategia en la Empresa Aseguradora en España, Ed. MAPFRE, Madrid, 1994. in Spain.

${ }_{19}$ With the exception of MAPFRE MUTUALIDAD, which owns 34.9 per cent of the Mutuals' premiums
} 
Table 5:

Differences in regulations for managing insurance companies

\section{Mutual Companies}

Non-profit-making institutions.

The mutualist has a dual nature, both as associate member and as insurance taker.

Mutualists are totally equal; no privileges. They have an economic fund accumulated in management; mutual fund.

Mutualists decide on the destination of each fiscal year's results: an increase in assets or return of the premium surplus. If results are negative, there may be an obligation for mutualists to pay a special levy, even if the fiscal year affected has elapsed.

\section{Joint-Stock Companies}

Mercantile company, set up to obtain profit. Shareholder as the owner of an aliquot part of the capital.

The shareholder's rights are linked to the number of shares he owns. There may be different rights.

Own economic fund: share capital. Shareholders participate in the distribution of company profits and assets resulting from liquidation. Shares are transferable. The shareholder responds for company debts up to the amount of his stake.

\section{Mutual Companies}

(Act 30/1995 and Regulations in force)

General meeting of the Mutual Company

Senior body which expresses the collective will, makes decisions though does not execute same. Meets by summoning all members; equal voting rights.

They approve annual accounts.

Board of Directors

Appointed by the meeting, exercises control, government and management of the Mutual Company. It lays down strategies, renders accounts, has powers of management and appoints guarantors.

\section{Chairman}

Legal representative appointed by the meeting or the Board. Controlled by the Board and may have executive powers delegated.

\section{Management}

Complies with the entity's day-to-day decisions by delegation.

\section{Management}

\section{Joint-Stock Companies}

(Text Ref. Companies Act 1564/1989)

\section{General meeting}

Senior body for decision making. Meets by summons. The Articles of Association may limit the right to attend to a minimum of shares which must group together. Each shareholder holds rights relating to his stake in the company.

Approves annual accounts.

Administrators

Are appointed by the general meeting. They represent the company statutorily.

Responsible to the company, creditors and shareholders.

\section{Board of Directors}

If administration is jointly entrusted too more than two people. The election of its members may proportionately reflect the shares they voluntarily bring together in voting. Appoints its Chairman, the Executive Committee and Managing Directors with due powers-ofattorney. 


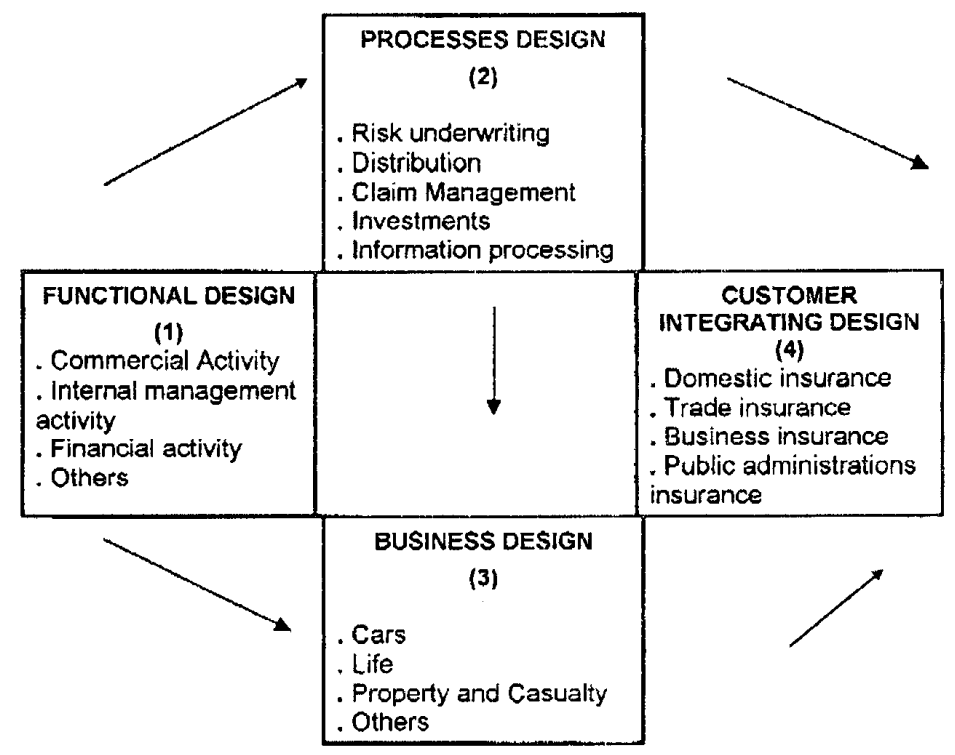

Figure 4: Evolution of insurance entities' internal organization

\section{Research on executive management for insurance entities: comparison between Mutual Companies and Joint-Stock Companies}

Each entity's management has the responsibility to multiply potential useful factors for companies. ${ }^{20}$ This involves exercising effective leadership to get a high commitment atmosphere at work and, in the end, a higher financial return for the company.

To manage strategically involves selecting successful strategies when combining perceptions about the environment the firm has to face with skills to determine companies' competitive values (Hax and Majluf, 1984). ${ }^{21}$

To examine the business response to these market challenges offered by both Mutual Companies and Joint-Stock Companies in Spain, the research was directed to entities' senior management with the aim of verifying which factors determine their competitiveness, knowing their management systems, and making comparisons between these two groups of institutions.

20 C. Pümpin and S. García Echevarría, Dinámica empresarial. Una nueva cultura para el éxito de la empresa. Madrid: Díaz de Santos, 1990.

21 A.C. Hax and N.S. Majluf, Strategic Management: an integrative perspective, Englewood Cliffs, New Jersey: Prentice Hall, 1984, p. 50. 
Table 6:

Top ten insurance companies (1999)

\begin{tabular}{|c|c|c|c|c|c|}
\hline $\begin{array}{l}1999 \\
\text { Mutual Companies }\end{array}$ & $\begin{array}{c}\text { Premiums } \\
\text { (million ptas) }\end{array}$ & $\begin{array}{c}\text { Market } \\
\text { share (\%) }\end{array}$ & $\begin{array}{l}1999 \\
\text { Joint - Stock Companies }\end{array}$ & $\begin{array}{c}\text { Premiums } \\
\text { (million ptas) }\end{array}$ & $\begin{array}{c}\text { Market } \\
\text { share (\%) }\end{array}$ \\
\hline $\begin{array}{l}\text { 1. MAPFRE MUTUALIDAD DE } \\
\text { SEG. Y REASEG. A PRIMA } \\
\text { FIJA }\end{array}$ & 180,177 & 3.3 & $\begin{array}{l}\text { 1. VIDACAIXA, S.A. SEGUROS } \\
\text { Y REASEGUROS, S.A. }\end{array}$ & 321,163 & 6.0 \\
\hline $\begin{array}{l}\text { 2. MUTUA MADRILEÑA } \\
\text { AUTOMOVILÍSTICA }\end{array}$ & 84,293 & 1.6 & $\begin{array}{l}\text { 2. EUROSEGUROS SEGUROS } \\
\text { Y REASEGUROS, S.A. }\end{array}$ & 278,435 & 5.2 \\
\hline $\begin{array}{l}\text { 3. FIATC MUTUA SEG. Y } \\
\text { REAS. A PRIMA FIJA }\end{array}$ & 35,444 & 0.7 & $\begin{array}{l}\text { 3. ALLIANZ SEGUROS Y } \\
\text { REASEGUROS, S.A. }\end{array}$ & 221,258 & 4.1 \\
\hline $\begin{array}{l}\text { 4. PELAYO, MUT. SEG. Y } \\
\text { REASEG. A PRIMA FIJA }\end{array}$ & 34,114 & 0.6 & 4. SEGUROS GÉNESIS & 165,944 & 3.1 \\
\hline $\begin{array}{l}\text { 5. MUTUA GENERAL DE } \\
\text { SEGUROS }\end{array}$ & 27,939 & 0.5 & $\begin{array}{l}\text { 5. LA ESTRELLA, S.A. SEG. Y } \\
\text { REASEGUROS }\end{array}$ & 136,671 & 2.5 \\
\hline $\begin{array}{l}\text { 6. AGRUPACIÓN MUTUA DEL } \\
\text { COMERCIO INDUSTRIA }\end{array}$ & 18,935 & 0.4 & 6. CAJA DE MADRID VIDA & 128,708 & 2.4 \\
\hline 7. ASEMAS & 13,077 & 0.2 & 7. IBERCAJA VIDA & 125,896 & 2.3 \\
\hline 8. EUROMUTUA & 12,439 & 0.2 & 8. AXA AURORA IBÉRICA & 117,520 & 2.2 \\
\hline $\begin{array}{l}\text { 9. P.S.N.-AGRUPACIÓN } \\
\text { MUTUAL ASEGURADORA. }\end{array}$ & 11,591 & 0.2 & 9. ZURICH ESPAÑA & 116,758 & 2.2 \\
\hline 10. MAPFRE AGROPECUARIA. & 10,499 & 0.2 & 10. VITALICIO SEGUROS & 115,919 & 2.2 \\
\hline Total, top ten Mutuals & 428,508 & 7.9 & Total, top ten Stock Co. ${ }^{\mathrm{s}}$ & $1,728,272$ & 32.2 \\
\hline
\end{tabular}




\subsection{Executive management analysis model}

Based on C. Pümpin's studies (1993), ${ }^{22}$ the analysis model we used was explored in preceding research (M.A. Martínez et al., 1998), ${ }^{23}$ including companies' competitiveness potential, their management systems and the manager's future view for each activity group.

The model is represented in Figure 5.

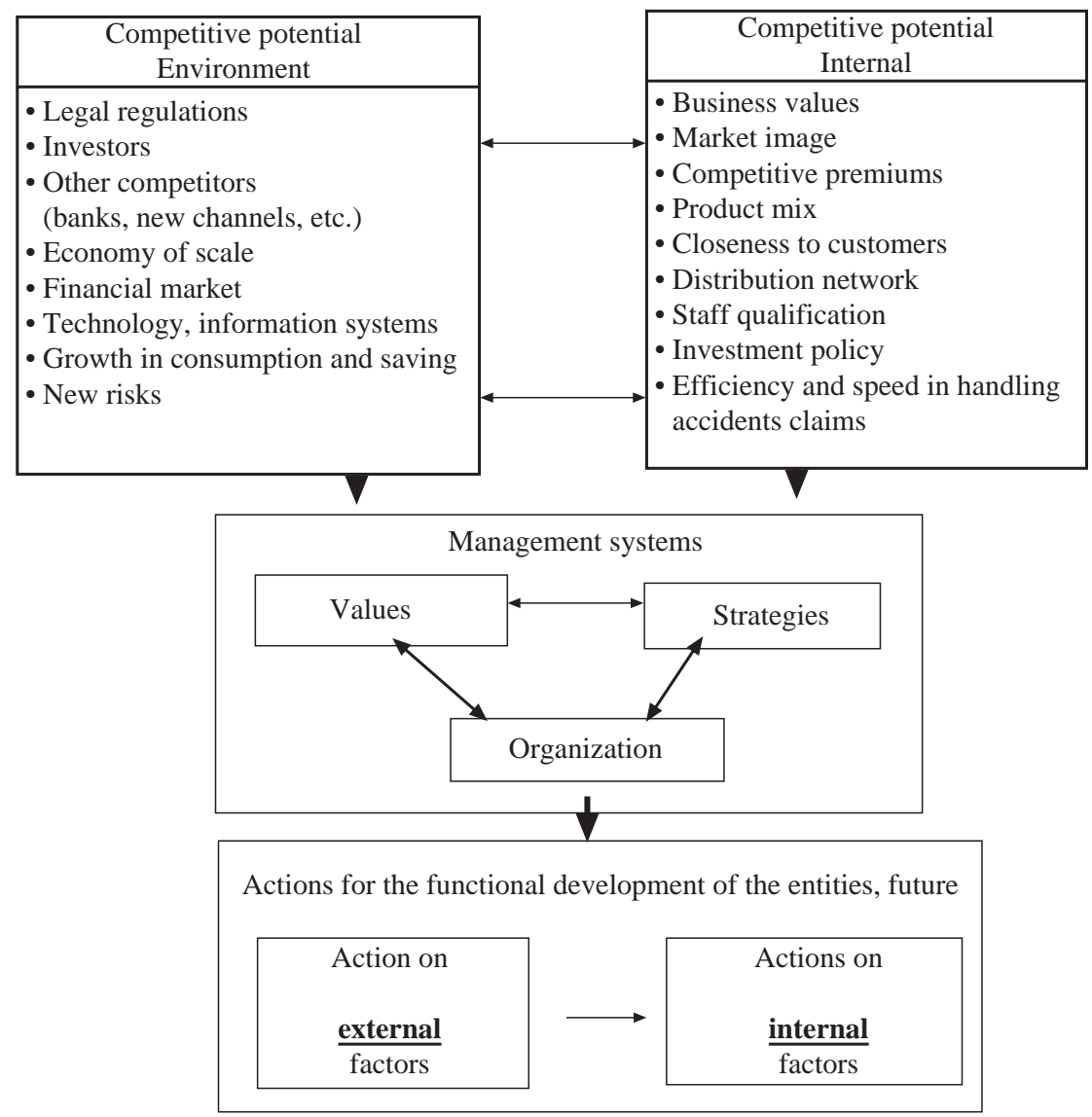

Figure 5: Executive management for insurance entities

22 C. Pümpin and S. García Echevarría, Estrategia Empresarial, Madrid: Ed. Díaz de Santos, 1993, p. 182.

23 M.A. Martínez Martínez et al., 1998. 
In order to operate the model, we have carried out an empirical analysis, conducting a survey with 16 questions grouped into five blocks and including 73 variables referring to entities' general data, their management systems (culture, strategy and organization) and the environmental and competitive factors which currently affect firms and those which could affect them in the future.

Generally reflection was requested for each question in the form of a choice of answers, evaluating them using a scale of 1 to 5 where 1 represents "slightly agree" and 5 "strongly agree" with the proposed answer.

Groupings of entities surveyed through multivariant statistical analysis with similar behaviour were also considered. ${ }^{24}$

\subsection{General sample data}

We obtained 14 completed questionnaires from Mutuals and 41 from Joint-Stock Companies to develop the empirical study. The survey was carried out in 1998.

\section{Mutual Companies}

- Questionnaire sent to 55 entities.

- Replies from 14 Mutuals: $25.4 \%$ of entities with $90.8 \%$ of sector's premiums volume.

- Entities with a long tradition. 13 have been operating for more than 25 years in Spain (mainly, with two exceptions).

- $86 \%$ operate throughout the Spanish market. The remaining $14 \%$ operate regionally.

- Mutuals' size distribution: More than 25,000 million ptas on premiums in 1996 (5 companies). Less than 25,000 million ptas on premiums in 1996 ( 9 companies). $50 \%$ have less than 500 employees and only one entity exceeds 1,000 (8 large Mutuals are between the replies).

- Business distribution by sector: $35.7 \%$ of Mutuals have their business concentrated in car insurance (over $70 \%$ of issues).

$50 \%$ of Mutuals do not operate life insurance and $78.6 \%$ do not operate pensions.

$42 \%$ do not operate general insurance (non-car) nor industrial insurance.

\section{Joint-Stock Companies}

- Questionnaire sent to 320 entities.

- Replies from 41 companies: 14 of entities with $16 \%$ of sector's premiums volume

- 16 companies have been operating for over 25 years in Spain (mainly, with five exceptions).

- $78 \%$ cover the whole Spanish territory.

- Joint-Stock Companies' (J-SCs) size distribution:

Over 25,000 million ptas (13 companies). Less than 25,000 million ptas (28 companies).

- $78 \%$ have less than 500 employees and only three entities exceed 1,000 employees.

- Business distribution by branches: $9.8 \%$ of J-SCs have their business concentrated in car insurance (over 70\% issues) and 26 companies do not operate in this sector.

$51.2 \%$ of J-SCs operate in the life insurance sector and 8 of them concentrate their activity (over 70\%).

$48.8 \%$ do not operate general insurance. $19.5 \%$ operate in the health insurance sector, concentrating their business therein ( 9 companies).

\footnotetext{
24 Processing carried out with SPSS Software, version 7.5.
} 
With reference to the samples obtained, the following observations must be made:

(1) The sample of Mutuals has their volume of activity skewed because those firms analysed sell more than 25,000 million ptas, and there is no representation for small companies.

(2) The sample of Joint-Stock Companies is also skewed: firstly regarding their field of activity (most of them are engaged in health insurance business) and, in addition, according to their turnover, there is little representation for "small entities" (those firms which sell less than 1,000 million pesetas) and an excess of companies whose business exceeds 25,000 million pesetas. Four of them are amongst the top ten and their market share is over 10 per cent.

The relative representativeness regarding their turnover is comparable to their share in the Spanish sector studied.

Due to the aforementioned slants, we cannot consider samples behave normally. Despite this fact, the values obtained from "t tests" carried out among groups of entities divided according to their production volume show that there are no large significant differences between Mutuals' and Joint-Stock Companies' behaviour (slightly over 93 per cent confidence).

\subsection{Environmental factors}

Strategic potentials represented environment represents in each entity's senior management opinion are analysed in two groups: (a) the main factors determining the future and (b) Spanish market opportunities (see Table 7).

Regarding the future, Mutuals are firstly concerned about new distribution channels and, to a lesser degree, about the entry of the banking sector or their entities' financial capacity increase requirements. Some of these concerns also appear in Joint-Stock Companies though somewhat dispersed between new channels and entry of the banking sector into insurance distribution.

With regard to Spanish market opportunities, large Mutuals and, to a lesser extent, JointStock Companies, both stress the future relevance of the life insurance market. This fact becomes even more evident when considering the 15 largest sized Joint-Stock Companies since they agree its importance in 82.4 per cent of cases.

\subsection{Internal competitive factors}

A list of essential factors in management is offered, from which we would isolate those shown in Table 8 .

For the companies overall, the most important variables are, for the Mutuals, the speed of response to a claim with 92.8 per cent of replies above "important", and closeness to customers with 85.8 per cent, whilst in the Joint-Stock Companies, speed of response to a claim is recognized by 95.1 per cent of the surveys and, in second place, human resource qualification as a factor of great importance for 87.8 per cent; this is even more significant for the largest Joint-Stock Companies which would seem to appreciate this factor more intensely, as 94.1 per cent answered a value higher than "important".

With regard to the most important distribution channel for the companies, the survey supports the idea that a large network of their own agents seems to be the most important (71.4 per cent for Mutuals and 60.9 per cent for Joint-Stock Companies) compared with other 
Table 7:

Most important items referring to the environment

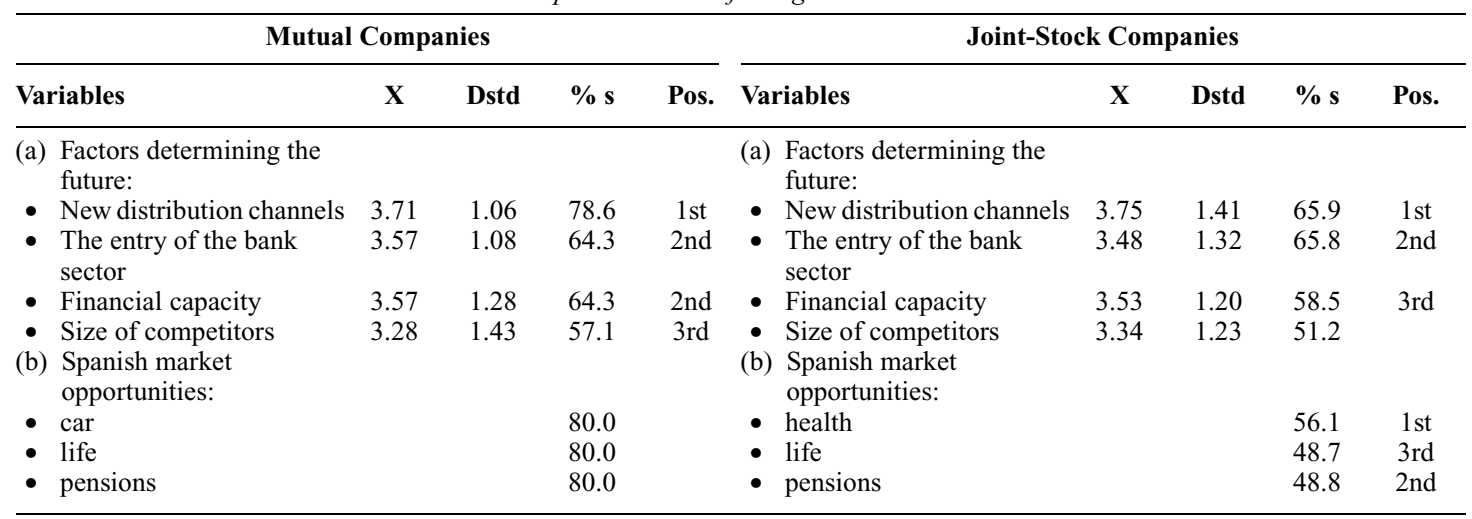

(I) Values for the total of companies. Not significant in differences by size.

(II) $\mathrm{X}=$ Average scale value; Dstd: Standard deviation; \% s: \% replies with mark above 4; Pos.: Relative position.

(III) Variables scale: 1 = Very unimportant; $2=$ Unimportant; $3=$ Some importance; $4=$ Important; and $5=$ Very important. 
Table 8:

Most important internal items

\begin{tabular}{|c|c|c|c|c|c|c|c|c|c|}
\hline \multicolumn{5}{|c|}{ Mutual Companies } & \multicolumn{5}{|c|}{ Joint-Stock Companies } \\
\hline Variables & $\mathbf{X}$ & Dstd & $\% s$ & Pos. & Variables & $\mathbf{X}$ & Dstd & $\% s$ & Pos. \\
\hline $\begin{array}{l}\text { (a) Total of companies: } \\
\text { speed of response to the } \\
\text { claim }\end{array}$ & 4.50 & 0.65 & 92.8 & $1 \mathrm{st}$ & $\begin{array}{l}\text { (a) Total of companies: } \\
\text { - speed of response to the } \\
\text { claim }\end{array}$ & 4.51 & 0.77 & 87.8 & $1 \mathrm{st}$ \\
\hline - closeness to the customer & 4.28 & 0.72 & 85.8 & 2 nd & $\begin{array}{l}\text { - human resource } \\
\text { qualification }\end{array}$ & 4.22 & 0.72 & 87.8 & $1 \mathrm{st}$ \\
\hline - competitive premiums & 4.21 & 0.80 & 78.5 & $3 \mathrm{rd}$ & - closeness to the customer & 3.97 & 1.12 & 82.9 & 2nd \\
\hline - image and tradition & 4.14 & 0.77 & 78.5 & $3 r d$ & - image and tradition & 3.80 & 1.16 & 63.4 & $3 \mathrm{rd}$ \\
\hline $\begin{array}{l}\text { - human resource } \\
\text { qualification }\end{array}$ & 4.07 & 0.73 & 78.5 & $3 r d$ & - breadth of agent network & 3.22 & 1.76 & 60.9 & 4 th \\
\hline - breadth of agent network & 3.78 & 1.05 & 71.4 & 4 th & & & & & \\
\hline (b) Five largest Mutuals: & & & & & $\begin{array}{l}\text { (b) Seventeen largest } \\
\text { companies: }\end{array}$ & & & & \\
\hline - closeness to the customer & 4.4 & 0.89 & 80 & $1 \mathrm{st}$ & $\begin{array}{l}\text { human resource } \\
\text { qualification }\end{array}$ & 4.17 & 0.52 & 94.1 & $1 \mathrm{st}$ \\
\hline - competitive premiums & 4.4 & 0.89 & 80 & $1 \mathrm{st}$ & $\begin{array}{l}\text { - speed of response to the } \\
\text { claim }\end{array}$ & 4.47 & 0.87 & 88.2 & 2nd \\
\hline & & & & & - closeness to the customer & 3.94 & 0.96 & 82.3 & $3 \mathrm{rd}$ \\
\hline
\end{tabular}

(I) $\mathrm{X}=$ Average scale value; Dstd: Standard deviation; \% s: \% replies with mark above 4; Pos.: Relative position.

(II) Variables scale: 1 = Very unimportant; $2=$ Unimportant; $3=$ Some importance; $4=$ Important; and $5=$ Very important. 
options such as direct sale (35.7 per cent for Mutuals and 48.8 per cent for Joint-Stock Companies) or Brokers (14.3 per cent for Mutuals and 14.7 per cent for Joint-Stock Companies).

\subsection{Management systems}

This topic has been divided into three sections: (a) strategic values of the institution, (b) management instruments used, and (c) predominant organizational form. Table 9 lists the most outstanding variables.

Regarding the values each institution seeks, Mutuals and Joint-Stock Companies agree in considering quality of services provided, closeness to customers, and results orientation as the most important.

The most characteristic strategies companies develop are, for all the survey Mutuals, the search for solvency improvement and speed of response to customers (with values above "important" for 92.8 per cent) in comparison with Joint-Stock Companies which do not give such current importance to their strategies, and underline their orientation towards improving quality ( 90.3 per cent), reducing costs and computerization ( 90.3 per cent).

The most common organizational form both for Mutuals and smaller Joint-Stock Companies is a functional structure which gives way to a divisional model for the largest companies (although highly dispersed in the sample of mercantile companies).

\subsection{Key factors for business future}

The survey also shows that both Mutuals and Joint-Stock Companies give greater importance (Table 10) to variables related to their internal management (technical efficiency for 92.8 per cent of Mutuals and 92.7 per cent of Joint-Stock Companies) compared with other possibilities of regulatory aids (such as fiscal benefits).

\subsection{Strategic clusters}

The survey analysis carried out is completed with a search for analogies in management systems and modes of strategic action in order to characterize the insurance entities studied.

The multivariant processing chosen was the "cluster" method which allow to classify companies (Mutuals and Joint-Stock Companies separately) while maximizing both the internal homogeneity of each group created and the heterogeneity of their grouped behaviours. The "Baverage" analysis was used for the hierarchical cluster method and the "k-means techique" for the non-hierarchical ${ }^{25}$ model.

In the case of Mutuals, for instrumental and organizational aspects of management, clearly defined groups will not be found, so, therefore, the analysis was only addressed for factors defining operative values and strategies.

\footnotetext{
25 The hierarchical method arises from the singular case as a group and uses the lesser averages of its "Euclidean" distances whilst the non-hierarchical one calculates the number of groups according to the remoteness of each singular case from the "centroid" thereof. See: R. Bisquerra Alzine, Introducción Conceptual al análisis multivariante, Vols I and II. Barcelona: Editorial PPU, 1989, C.M. Cuadras, Métodos de análisis multivariante, Barcelona: Editorial Enniban, 1981. F. Ruiz Mayo et al., Análisis Estadístico de encuestas. Datos cualitativos. Madrid: Editorial A. C., 1995.
} 
Iable Y:

Predominant management systems

\begin{tabular}{|c|c|c|c|c|c|c|c|c|c|}
\hline \multicolumn{5}{|c|}{ Mutual Companies } & \multicolumn{5}{|c|}{ Joint-Stock Companies } \\
\hline Variables & $\mathbf{X}$ & Dstd & $\% \mathrm{~s}$ & Pos. & Variables & $\mathbf{X}$ & Dstd & $\% \mathrm{~s}$ & Pos. \\
\hline$\left(a_{1}\right)$ Values of the institution & & & & & $\left(a_{1}\right)$ Values of the institution & & & & \\
\hline - Quality of services provided & 4.78 & 0.42 & 100 & $1 \mathrm{st}$ & - Quality of services provided & 4.39 & 0.99 & 80.05 & $1 \mathrm{st}$ \\
\hline - Close customer & 4.42 & 0.64 & 92.8 & 2nd & - Close customer & 4.09 & 0.76 & 80.05 & 2nd \\
\hline - Orientation results & 4.14 & 0.66 & 85.7 & $3 r d$ & - Orientation results & 4.07 & 0.68 & 80.05 & 3 rd \\
\hline$\left(\mathrm{a}_{2}\right)$ Institution's strategies & & & & & $\left(\mathrm{a}_{2}\right)$ Institution's strategies & & & & \\
\hline - Solventy improvement & 4.52 & 0.51 & 100 & $1 \mathrm{st}$ & - Orientation towards quality & 4.51 & 0.84 & 90.3 & $1 \mathrm{st}$ \\
\hline - Quickly response to customer & 4.43 & 0.85 & 92.8 & 2nd & $\begin{array}{l}\text { - Orientation towards reduction } \\
\text { costs and data processing }\end{array}$ & 4.39 & 0.66 & 90.3 & 2nd \\
\hline - Orientation towards quality & 4.42 & 0.64 & 92.8 & $3 \mathrm{rd}$ & - Quick response to customer & 4.48 & 0.77 & 87.8 & 3rd \\
\hline $\begin{array}{l}\text { Orientation towards reducing } \\
\text { costs and data processing }\end{array}$ & 4.28 & 0.72 & 85.7 & 4 th & & & & & \\
\hline
\end{tabular}

(b) Management instruments

- Strategic plan: drawn up by 57.1\% Mutuals

- Annual budget: drawn up by 85.7 Mutuals

(c) Form of organization largest Mutuals

- Divisional model (branches)

- Coord. through senior management smaller Mutuals

- Functional model 4.60 4.80 0.54

0.44

3.44

1.81

(I) X: Average scale value; Dstd: Standard deviation\%; \% s: \% replies with mark above 4; Pos.: Relative position.

(II) Variables scale: $1=$ Very unimportant; $2=$ Unimportant; $3=$ Some importance; $4=$ Important; and $5=$ Very important (b) Management instruments

- Strategic plan: drawn up by $75.6 \%$ of Joint-Stock Companies

- Annual budget drawn up by 97.6 of Joint-Stock Companies

(c) Form of organization largest Joint-Stock Companies

$\begin{array}{llll}\text { - Divisional model } & 3.17 & 1.66 & 41.2\end{array}$

(branches)

- Coord. through senior management (smaller Joint-Stock Companies)

$4.11 \quad 1.11 \quad 88.3$

$\begin{array}{lll}.50 & 1.40 \quad 66.0\end{array}$


Table 10:

Predominant management systems

\begin{tabular}{|c|c|c|c|c|c|c|c|c|c|}
\hline \multicolumn{5}{|c|}{ Mutual Companies } & \multicolumn{5}{|c|}{ Joint-Stock Companies } \\
\hline Variables & $\mathbf{X}$ & Dstd & $\% s$ & Pos. & Variables & $\mathbf{X}$ & Dstd & $\% s$ & Pos. \\
\hline $\begin{array}{l}\text { Efficiency, } \\
\text { technical } \\
\text { management }\end{array}$ & 4.50 & 0.65 & 92.8 & $1 \mathrm{st}$ & $\begin{array}{l}\text { Efficiency, } \\
\text { technical } \\
\text { management }\end{array}$ & 4.36 & 0.76 & 92.7 & $1 \mathrm{st}$ \\
\hline $\begin{array}{l}\text { Investment, } \\
\text { information } \\
\text { technology }\end{array}$ & 4.42 & 0.75 & 89.7 & 2nd & $\begin{array}{l}\text { Investment, } \\
\text { information } \\
\text { technology }\end{array}$ & 4.24 & 0.88 & 87.8 & 2nd \\
\hline $\begin{array}{l}\text { - Sale through } \\
\text { intermediaries }\end{array}$ & 3.78 & 1.25 & 64.3 & $3 \mathrm{rd}$ & $\begin{array}{l}\text { - Process } \\
\text { re-engineering }\end{array}$ & 3.82 & 1.18 & 63.4 & $3 \mathrm{rd}$ \\
\hline - Fiscal benefits & 3.28 & 1.20 & 50.0 & & - Fiscal benefits & 2.78 & 1.37 & 36.6 & \\
\hline
\end{tabular}

Table 11 contains the analysis of variance for the variables examined. Most factors contributing to reinforcing differences between groups are obtained through processing, in order to label their type.

For mutual entities, six differentiated clusters were found, where four groups were identified with a labelled orientation, such as:

One Mutual oriented towards "integral competitiveness".

Seven Mutuals oriented towards "nationwide growth and autonomy".

Two Mutuals with a certain preference for "merging".

Two Mutuals with greater difference towards considering predominant a future "company transformation" strategy.

Two other groups had mixed strategies without defining their type.

For those entities whose legal form is the Joint-Stock Company, seven clusters were found, of which five with labelled strategic orientations defined were identified:

25 companies oriented towards "company change and external growth".

Two companies with a preference towards generalized "company expansion".

Two companies particularly oriented towards "company change".

Three companies preferably oriented towards trust ("confidence") as a differentiating value from competitors.

Three companies oriented towards "growth outside their traditional sphere" together with another two groups with mixed, unlabelled orientations.

Tables 12 and 13 summarize characteristics for the groups found.

\section{Conclusions}

The foregoing paragraphs include the main facts that show the major transformation the Spanish insurance sector is undergoing, which heavily influence their competitiveness. 
Table 11:

\begin{tabular}{|c|c|c|c|c|c|c|}
\hline \multirow{2}{*}{$\frac{\text { Variance analysis }}{\text { Variables studied }}$} & \multicolumn{3}{|c|}{ Mutual Companies } & \multicolumn{3}{|c|}{ Joint-Stock Companies } \\
\hline & DF & $\mathbf{F}$ & Probability & DF & $\mathbf{F}$ & Probability \\
\hline \multicolumn{7}{|c|}{ Values of identification and their corporate culture: } \\
\hline Confidence the environment inspires & 8 & 1.6000 & 0.264 & 33 & 5.7085 & $0.000^{*}$ \\
\hline Quality of services provided & 8 & 1.0400 & 0.458 & 33 & 2.5808 & $10.031^{* *}$ \\
\hline Trade mark & 8 & 5.4286 & $0.018^{* *}$ & 33 & 8.8324 & $0.000^{*}$ \\
\hline $\begin{array}{l}\text { Closeness of employees and agents to the } \\
\text { customer }\end{array}$ & 8 & 0.9672 & 0.481 & 33 & 3.1102 & $0.012^{* *}$ \\
\hline Orientation towards results and costs & 8 & 5.1368 & $0.021^{* *}$ & 33 & 2.4595 & $0.038^{* *}$ \\
\hline $\begin{array}{l}\text { Orientation towards the integration and } \\
\text { commitment of the staff themselves }\end{array}$ & 8 & 8.0582 & $0.005^{*}$ & 33 & 3.5916 & $0.006^{*}$ \\
\hline \multicolumn{7}{|l|}{ Strategies oriented towards: } \\
\hline $\begin{array}{l}\text { Growing in their traditional geographical } \\
\text { sphere }\end{array}$ & 8 & 7.4034 & $0.007^{*}$ & 33 & 2.3144 & $0.049^{* *}$ \\
\hline $\begin{array}{l}\text { Growing outside their traditional } \\
\text { geographical } \\
\text { sphere }\end{array}$ & 8 & 5.2267 & $0.020^{* *}$ & 33 & 9.4021 & $0.000^{*}$ \\
\hline Merging with other insurance entities & 8 & 14.3294 & $0.001^{*}$ & 33 & 7.7536 & $0.000^{*}$ \\
\hline Transforming the company's legal form & 8 & 7.9111 & $0.006^{*}$ & 33 & 5.4284 & $0.000^{*}$ \\
\hline Diversifying branches and insurers & 8 & 2.1938 & 0.155 & 33 & 11.0389 & $0.000^{*}$ \\
\hline Production with highly competitive prices & 8 & 2.2775 & 0.144 & 33 & 1.8508 & 0.110 \\
\hline $\begin{array}{l}\text { Reducing costs and computerizing } \\
\text { management }\end{array}$ & 8 & 1.6681 & 0.248 & 33 & 0.8231 & 0.575 \\
\hline Quality & 8 & 0.3673 & 0.861 & 33 & 4.8476 & $0.001^{*}$ \\
\hline Speed of response to the customer & 8 & 0.4505 & 0.802 & 33 & 2.7355 & $0.024^{* *}$ \\
\hline Improving solvency & 8 & 0.6588 & 0.665 & 33 & 6.9779 & $0.000^{*}$ \\
\hline
\end{tabular}

Variables contributing towards defining types of groups: ${ }^{*} P<0.01 ;{ }^{* *} P<0.05$. 
Table 12:

Predominant values and strategies in Mutuals

\begin{tabular}{ll}
\hline Number of Mutuals & Group's preferential orientations \\
\hline Cluster 1 & "Integral competitiveness" \\
One Mutual & - Trade mark \\
& - Orientation towards diversifying branches \\
& - Growth outside the traditional geographical sphere \\
& - Production with competitive prices \\
Cluster 2 & "Growth and autonomy" \\
Seven Mutuals & - Orientation towards growth in their traditional geographical \\
& - Rejection of merging with other entities. \\
Cluster 3 & "Merger" \\
Two Mutuals & - Certain orientation towards growth in their traditional \\
& geographical sphere \\
Cluster 4 & - Clear orientation to merging with other entities. \\
Two Mutuals & "Transformation" \\
Clusters 5 and 6 & - Orientation towards company transformation \\
One Mutual and one Mutual & "Certain orientation towards merging
\end{tabular}

A Mutual company particularly requires management solutions in order to face these challenges; strategic changes to take advantage of the value of their serving spirit to mutualists (customers) adding value to what is offered, even though this change is accompanied by certain company transformations leading entities to a more competitive size. The small Mutual has to modernize its management, as shown when appraising improved technique and information technology as a key to its future success whilst at the same time having to become used to work through business alliances with other entities.

Joint-Stock Companies and mutuals are concerned with how the new distribution channels are multiplying, although this variable is more intense for mutuals.

The strategic value of the human resource qualification would appear patent with greater intensity and preference for the joint-stock companies than for mutuals. The latter are more concerned with improving their competitiveness to benefit customers offering highly competitive premiums.

The organization of the small companies surveyed, both Joint-Stock and Mutuals, has a predominantly functional approach (making techno-commercial activities specialized) with a trend to grow through dividing their structure whilst at the same time diversifying their branches. Materialized instruments of management and co-ordination, such as strategic plans (only drawn up by 57 per cent of mutuals surveyed) are more common in Joint-Stock Companies.

Finally, and in accordance with analysed data, we should add the importance of transformations mentioned for the insurance sector overall in Spain, which must seek competitiveness on three complementary fronts: management efficiency, orientation towards 
Table 13:

Predominant values and strategies in Joint-Stock Companies

\begin{tabular}{|c|c|}
\hline Number of companies & Group's preferential orientations \\
\hline Cluster 1 & "Company change and external growth" \\
\hline 25 Joint-Stock Companies & $\begin{array}{l}\text { - Heavy orientation towards growth via mergers } \\
\text { - Heavy orientation towards company transformation } \\
\text { - Certain trend towards growth outside their traditional } \\
\text { sphere }\end{array}$ \\
\hline Cluster 2 & "Company expansion" \\
\hline Two Joint-Stock Companies & $\begin{array}{l}\text { - Heavy orientation towards branch diversification } \\
\text { - Heavy orientation towards company transformation } \\
\text { - Heavy orientation towards growth outside their traditional } \\
\text { sphere }\end{array}$ \\
\hline Cluster 3 & "Company change" \\
\hline Two Joint-Stock Companies & $\begin{array}{l}\text { - Heavy orientation towards company transformation. } \\
\text { - Certain trend towards merging with other entities }\end{array}$ \\
\hline Cluster 4 & "Confidence" \\
\hline Three Joint-Stock Companies & $\begin{array}{l}\text { - Orientation towards the value of confidence it inspires } \\
\text { - Certain trend towards merging with other entities } \\
\text { - Certain trend towards diversification by branches } \\
\text { - Very weak orientation towards service quality. }\end{array}$ \\
\hline Cluster 5 & "External growth" \\
\hline Three Joint-Stock Companies & $\begin{array}{l}\text { - Heavy orientation towards growth outside their traditional } \\
\text { sphere } \\
\text { - Very weak orientation towards relations with the customer } \\
\text { - Very weak orientation towards improving solvency. }\end{array}$ \\
\hline Clusters 6 and 7 & "Unidentified mixed" \\
\hline
\end{tabular}

customers and achieving his/her loyalty and the capacity to combine autonomy with the search for a business size suited to the European context.

\section{REFERENCES}

AISAM, 1992, "Equity funding and taxation of Mutual Insurance Co", Grupo de Trabajo.

ADKINS, J.B., 1997, "The policyholder perspective on mutual holding companies conversions", Journal of Insurance Regulation, 16, autumn, pp. 5-15.

ATTALI, J., 1997, "Geopolítica de los riesgos del siglo XXI", Gerencia de Riesgos, 8.

AVALOS MUOZ, L.M., 1990, "El mutualismo en España y en la Europa Comunitaria”, Previsión y Seguro, 6, JulioAgosto, Madrid.

BEGG, I. and GREEN, D., 1996, "Panorama de las tendencias clave en el mercado de Seguros mundial”, South Bank University, London (Dictado en la Conferencia Mundial de Seguros, Ginebra, 4 July).

BERNAL ZÚIGA, J.L., 1994, "La crisis del mutualismo privado", Actualidad Aseguradora, 16, Madrid.

BIGOT, J., 1992, Enterprises et organismes d'assurances, (9th edn)(6D). Paris.

BISQUERRA ALZINE, R., 1989, Introducción conceptual de análisis multivariante, Vols I and II. Barcelona: Editorial PPU.

BYRNE, N., 1998, "The European Insurance Outlook 1999-2005”, Datamonitor.

CAPA, 1996, "L'organization et la competitivité des enterprises”, Capa, Paris, February. 
CASTElO MATRÁN, J. and GUARDiOlA, A., 1992, Diccionario MAPFRE de Seguros. Madrid: Editorial MAPFRE.

CEA, 1990, Les droits du contrat d'assurance. Paris.

CEA, 1999, European Insurance in Figures.

CERCOLA, R. and COLETTI, M., 1996, "La empresa que asegura a sus clientes". Madrid: Ed. Mapfre.

CINCO DÍAS, 1997, "Prudential reaviva el debate sobre la desmutualización del seguro", Madrid. 16 February.

COCHRAN, W.G., 1976, Técnicas de Muestreo. Mexico, CECSA.

CUADRAS, C.M., 1981, Métodos de análisis multivariantes. Barcelona, Editorial Ennibar.

DIRECCIÓN GENERAL DE SEGUROS, “Memorias Estadísticas”. España (1987-1999).

EL PAIS, 1997, "Las Mutuas están en forma”, 12 January.

ESTEBAN JÓDAR, L., 1993, “El mercado español de seguros”, ICE no. 175, March, pp. 15-44.

EUROSTAT, 1997, "Statistiques des Services d'assurance".

FARNY, D., 1984, "Decisiones estratégicas de política empresarial con que enfrentarán los aseguradores europeos hasta final de siglo", Mutualité de AISAM, Paris.

FARRERES BOCHACA, A., 1997, "El Mutualismo de Seguros en España”, AISAM, 40, Paris.

FINANCIAL TIMES GROUP, 1996, "Los seguros en Europa hasta el año 2010. Enfrentarse al reto de los clientes", Newsletter, Recoletos Cía. Ed. Madrid.

FORTUNE, 2000, "Global 5 Hundred”, Fortune, 24 July 2000.

FUNDACION MAPFRE ESTUDIOS, 1999, "El mercado español de Seguros en 1998”, Madrid, July.

GARRIDO y COMAS, J.J., 1992, El mutualismo privado en la Europa del Siglo XX. Madrid: Editorial MAPFRE.

GARRIGUES, J., 1983, Contrato de Seguro Terrestre. Madrid.

GONZÁLEZ, Y., 1995, "Análisis de la demanda del seguro sanitario privado", Cuaderno de la Fundación, Madrid.

GUINN, P. and COLLINS, S., 1997, "Having it both ways”, Best's Review, September, pp. 66-69.

HAMMER, M. and CHAMPY, J., 1983, Re-engineering the Corporation: a manifesto for Business Revolution. New York: Harper Collins.

HAX, A.C. and MAJLUF, N.S., 1984, Strategic Management: an integrative perspective. Englewoods Cliffs, New Jersey: Prentice Hall.

JEAN CHARLES, G. and LA FARGUE, G., 1994, Les Mutuelles face à L'Europe. Paris: De Verneuil.

JENSEN, M.C. and MECKLING, W.H., 1976, “Theory of the firm", Insurance of Financial Economics, 3, 1, 4 October.

LADO COUSTÉ, N. and MARTÍNEZ MARTÍNEZ, M.A., 1997, "Market orientation and business performance in the Spanish Insurance Sector", The Geneva Papers on Risk and Insurance, October, pp. 571-590.

LARRAMENDI, I.H., 1984, "El futuro de las mutuas de seguros en España", Riesgo, November.

LOMA-HAY GROUP, 1995, "Leadership for the $21^{\text {st }}$ century", Hay Co.

Ley 30/1995 de 8 de noviembre de Ordenación y Supervisión de Seguros Privados. España.

MALEVILLE, M.H., 1992, "Critères communs d'une structure méconnue: les mutuelles”, J.C.P. de E., 7, 182.

MALEVILLE, M.H., 1996, "Vers un statut de la mutualité européenne", Revue General des assurances terrestres, 4, Paris.

MANSILLA, F., 1992, “El seguro español y las mutuas”, Conferencia XVIII Asamblea General AISAM, Barcelona, October.

MARTÍNEZ MARTÍNEZ, M.A., 1994, Organización y estrategia en la empresa aseguradora en España. Madrid: Editorial MAPFRE.

MARTÍNEZ MARTÍNEZ, M.A., 1996, "Evolución de la distribución del Seguro: el caso de la vinculación BancaSeguros en España”, Conferencia pronunciada en Bogotá, 6 July.

MARTÍNEZ MARTÍNEZ, M.A., 1998a, "Las Mutualidades de Seguros Generales como entidades de propiedad colectiva: cambios en su gestión directiva”, Revista Española de Seguros, January, pp. 51-88.

MARTÍNEZ MARTÍNEZ, M.A., 1998b, "Nuevas necesidades del consumidor de seguros al inicio del siglo XXI. El Caso Español”, Conferencia dictada en las $2^{\text {as }}$ Xornadas Universitaria do Seguro, Publicado resumen Santiago de Compostela, 29 April.

MICHEL, P., 1996, "Mutualidades de Seguros y directivas europeas sobre el seguro", Mutualité de AISAM, 47/2, Paris.

Newsletters, "Los Seguros en España hasta el año 2010” Recoletos Cía. Ed. Madrid, 1996.

PÜMPIN, C. and GARCÍA ECHEVARRÍA, S., 1993, Estrategia Empresarial. Madrid: Ed. Díaz de Santos.

REDLER, E., 1994, "European financial sector. Trends, practices and effects", Financial Times Management Report, London.

RUIZ MAYO, F. et al., 1995, Análisis estadístico de encuestas. Datos cualitativos. Madrid: Ed. A.C.

SCISM, L., 1997, "Las mutuas de EE.UU”, Wall Street Journal, pub. por Cinco Días (España), Madrid, 30 April. 
SUGRANYES, D., 1994, "Necesidad de Capital de las Mutuas Aseguradoras", Conferencia pronunciada en Intl. Insurance Conference, Zurich, 28-29 November.

SWISS RE, 1996, "Desregulación y apertura del mercado: El seguro europeo en el umbral de una nueva era de competencia", Sigma, 7.

SWISS RE, 1999, "Las mutuas de seguros: Una especie en peligro de extinción?, Sigma, 4.

UNESPA, 1987-1995, "Informes anuales del sector español".

VAN DEN BERGHE, L. and WERWEIRE, K., 2000, "Convergence in the financial services industry", The Geneva Papers on Risk and Insurance. Issues and Practice, 25, 2, April, pp. 262-272.

WEIGEL, H.J., 1996, "El futuro del seguro mutuo", AISAM, 47, Paris. 